\title{
Effects of Culture Conditions on Growth and Biochemical Profile of Chlorella Vulgaris
}

Rekha Sharma1, Gajendra Pal Singh ${ }^{2}$ and Vijendra K. Sharma ${ }^{1 *}$

${ }^{1}$ Department of Botany, MSJ Government PG College, Bharatpur-321 001, Rajasthan, India

${ }^{2}$ Department of Botany, University of Rajasthan, Jaipur-302 055, Rajasthan, India

\begin{abstract}
The effects of culture conditions at different temperature and light regimes on growth and the contents of chlorophyll-a, chlorophyll-b, total carotenoids, total protein and total free amino acids of Chlorella vulgaris were determined. The growth of $C$. vulgaris in terms of optical density $(0.42$ at $670 \mathrm{~nm})$, cell count $(440 \times 104 \mathrm{cells} / \mathrm{ml})$ and dry weight $(30.2 \mathrm{mg} / 50 \mathrm{ml})$, and the amount of chlorophyll- a $(2.16 \%)$, chlorophyll- b $(0.59 \%)$ and total protein, was found higher at the temperature $25-30^{\circ} \mathrm{C}$ and natural day light receiving through the north facing window of the growth room. Although, the amount of total carotenoids $(0.440 \%)$ and free amino acids $(834 \mu \mathrm{g} / \mathrm{gm}$ fresh weight) were found maximum in continuous light at $30-35^{\circ} \mathrm{C}$, not much differences in the amount of carotenoids $(0.385 \%)$ and free amino acids $\left(822 \mu \mathrm{g} / \mathrm{gm}\right.$ fresh weight) were found at $25-30^{\circ} \mathrm{C}$ and natural day light. The natural day light at $25-30^{\circ} \mathrm{C}$ was also proved proficient, as distinct banding pattern with unique polypeptides such as $15 \mathrm{KDa}, 47 \mathrm{KDa}$ and $50 \mathrm{KDa}$, on the other hand, $23 \mathrm{KDa}, 26 \mathrm{KDa}$ and $36 \mathrm{KDa}$ appeared in all samples, these bands were not affected by light and temperature. Our results indicate that among all five culture conditions tested, the cultures kept at north facing window receiving natural day light at temperature $25-30^{\circ} \mathrm{C}$, show best growth and higher contents of biochemicals that will be beneficial to use Chlorella for high nutritive purpose.
\end{abstract}

Keywords: Chlorella; Culture condition; Growth; Chlorophylls; Carotenoids; Proteins; Amino acids

Abbreviations: CC: Cell Count; Chl-a: Chlorophyll-a; Chl-b: Chlorophyll-b; DW: Dry Weight; FW: Fresh Weight; OD: Optical Density

\section{Introduction}

Chlorella is the most cultivated eukaryotic green micro alga, as it is widely used as a health food and feed supplement, as well as in the pharmaceutical and cosmetics industry. It contains proteins, carotenoids, lipids, immunostimulator compounds, polysaccharides, vitamins, antioxidants and minerals. The growth of algae is a function of many factors, including nutrients, $\mathrm{pH}$, salinity, temperature and light (duration and intensity). Among these factors, the light that directly influences photosynthetic mechanism is an important factor in defining optimal conditions for the culture [1]. In the presence of non-limiting nutrients, the efficiency of microalgal culture remains controlled, mainly by light intensity and temperature. Photosynthesis of phytoplankton is influenced by natural factors, such as temperature and irradiance [2]. These factors influence the nutritional value of phytoplankton such as protein, carbohydrate, lipid, amino acid and pigments composition [3]. These specific chemicals attributes will not follow similar trends with changing temperature and light conditions [4]. The effects of irradiance and photoperiod on the biomass and fatty acid composition of Chlorella vulgaris, were also examined [5]. It has been long known that direct sunshine is harmful to algal cultures. Under natural conditions, receiving direct rays of the sun rarely fall on an alga, and a few centimeters of interposed water are sufficient to reduce the harmful effects. In the natural habitats, algae grow predominantly in diminished light; hence cultures should be placed in the window, where direct sun light could be avoided.

Refer to the previous work in Prochlorococcus sp., the effect of illumination on cell growth cycle were examined [6], and in Chlamydomonas geilteri the growth to be dependent on a wide range of temperature [7]. The growth of Chlamydomonas ulvaensis and its polysaccharide contents, to be dependent on light intensity, and temperature range [8] and the effects of various lights on the growth of Pithophora kewensis, Cladophora flexuosa, Chaetomorpha melagonium and Rhizoclomium riparium, were also observed [9]. The temperature dependent sensitivity of growth and photosynthesis of Scenedesmus obliquus and Navicula pelliculosa [10], and the effect of varied light intensities and temperature on desmids, have been reported [11,12]. These workers have observed that temperature as well as illumination conditions, play an important role in defining varied morphological factors.

The aim of the present study is to evaluate the influence of different culture conditions of temperature and illumination on the growth and biochemical profile of C. vulgaris, and to optimize the best culture condition.

\section{Materials and Methods}

\section{Test organism and culture conditions}

The experimental organism Chlorella vulgaris was isolated from Mawtha, a fresh water pond, $\mathrm{pH} 7.3$, near Amber Fort in Jaipur, Rajasthan (India), cultured on Modified Chu-10 medium and maintained on the same medium by regular subculturing in every two weeks, as previously described [13]. Experiments to evaluate the effect

*Corresponding author: Vijendra K. Sharma, Department of Botany, MSJ Government PG College, Bharatpur-321 001, Rajasthan, India, Tel: +91 9414454668 ; E-mail: sharmavijendrak@yahoo.co.in

Received August 06, 2012; Accepted September 08, 2012; Published September 13, 2012

Citation: Sharma R, Singh GP, Sharma VK (2012) Effects of Culture Conditions on Growth and Biochemical Profile of Chlorella Vulgaris. J Plant Pathol Microb 3:131. doi:10.4172/2157-7471.1000131

Copyright: ( 2012 Sharma R, et al. This is an open-access article distributed under the terms of the Creative Commons Attribution License, which permits unrestricted use, distribution, and reproduction in any medium, provided the original author and source are credited. 
of different culture conditions on C. vulgaris, were carried out in the departmental laboratory.

In order to find out the optimum culture condition, the cultures were subjected to five different conditions of temperature and light regimes. In the growth room, light was provided by fluorescent tube lights ( $40 \mathrm{~W}$ ) having 2500 Lux intensity, and were fixed at a distance of $64 \mathrm{~cm}$ from the cultures in constant and alternate light conditions. One set of five different culture conditions were placed in the laboratory in window, which was facing north, for providing natural day and dark periods. The intensity of natural day light was as an average 2700 Lux. The following culture conditions set in the growth room were used in the present study:

1. Constant light at temperature $25-30^{\circ} \mathrm{C}$ (Set I)

2. Alternate light and dark period $(12: 12 \mathrm{hr})$, at $25-30^{\circ} \mathrm{C}$ (Set II)

3. Constant light at $30-35^{\circ} \mathrm{C}$ (Set III)

4. Alternate light and dark period $(12: 12 \mathrm{hr})$, at $30-35^{\circ} \mathrm{C}$ (Set IV) (Set V)

5. Natural day and dark period, at north facing window $25-30^{\circ} \mathrm{C}$

\section{Growth measurement}

Three test tube sets for each culture condition, containing $10 \mathrm{ml}$ of the culture medium and $2 \mathrm{ml}$ of freshly growing cultures were subjected to different culture conditions, and their growth were followed through optical density (OD), cell count (CC) and dry weight (DW). Optical density was recorded by using colorimeter at $670 \mathrm{~nm}$, and cell count examination was performed using haemocytometer (Neubauer improved). Dry weight was determined using $50 \mathrm{ml}$ algal sample of culture which was filtered on a Whatman GF/C Filter, rinsed with distilled water, and weighed after drying at $60^{\circ} \mathrm{C}$ for overnight. Simultaneously, five conical flasks containing $250 \mathrm{ml}$ of each medium and $50 \mathrm{ml} \mathrm{C}$. vulgaris were subjected for estimation of pigments, total protein and total free amino acids. All medium in the flask and test tubes were sterilized in an autoclave at $121^{\circ} \mathrm{C}$ for $20 \mathrm{~min}$., before inoculation. Cultures were shaken gently, thrice a day to avoid clumping and accelerate the growth process. Experiment for each medium was carried out in triplicates. Observations were carried out over a period of five weeks, after initial readings.

\section{Estimation of pigments}

Chlorophyll content of the samples were extracted in $90 \%(\mathrm{v} / \mathrm{v})$ acetone, and chlorophyll-a, b estimated by Parson and Strickland method [14]. Carotenoid content of the samples were extracted in $80 \%$ $(\mathrm{v} / \mathrm{v})$ acetone, and estimated by Jensen method [15].

\section{Estimation of proteins}

Protein content of the samples was estimated quantitatively by Lowry [16] by dry biomass, using bovine serum albumin (BSA) as standard. Qualitatively, the proteins were estimated by the SDSPAGE analysis, which was carried out according to Laemmli [17]. For extraction of proteins, the samples were homogenized with lysis buffer containing 0.5M Tris-HCl, $8 \mathrm{M}$ Urea, $5 \%$ (w/v) SDS, $20 \%$ (v/v) Glycerol and $10 \%(\mathrm{v} / \mathrm{v}) \beta$-Mercaptoethanol; final pH 6.8 and centrifuged at $4^{\circ} \mathrm{C}$ for $20 \mathrm{~min}$ at 10,000 $\mathrm{rpm}$. Protein extract was used for SDS-PAGE analysis, using a $12 \%$ polyacrylamide gel containing $0.1 \%$ SDS and the buffer system of Laemmli. Gels were run at $20^{\circ} \mathrm{C}$ at a constant current of $15 \mathrm{~mA}$, for approximately $4 \mathrm{~h}$. Gels were stained with $1 \%$ Coomassie brilliant blue, for protein visualization.

\section{Estimation of amino acids}

Quantitative estimation of free amino acid was carried out, by method of Lee and Takahashi [18]. One milliliter aliquot of the alcoholic extract was mixed with $5 \mathrm{ml}$ of ninhydrin reagent and boiled in a boiling water bath for 20-25 minutes, and after cool down, absorbance was recorded at $570 \mathrm{~nm}$ with spectrophotometer. Glycine was used as a standard.

\section{Results}

\section{Biomass production}

Estimation of growth through OD, CC and DW of Chlorella vulgaris in different culture conditions shows different growth pattern, in spite of all culture conditions started with similar initial inoculums (Figures 1-3). Among all five culture conditions, north facing window receiving natural day light at temperature $25-30^{\circ} \mathrm{C}$ shows best growth for nutritive purpose of Chlorella, and followed by alternate light and dark period at $25-30^{\circ} \mathrm{C}$, continuous light at $25-30^{\circ} \mathrm{C}$ and poor growth was observed in continuous light at $30-35^{\circ} \mathrm{C}$.

In alternate light and dark (12:12 hr) in both the sets of temperature, i.e. $25-30^{\circ} \mathrm{C}$ and $30-35^{\circ} \mathrm{C}$, growth was higher at $25-30^{\circ} \mathrm{C}$, where $\mathrm{OD}$ was increased 3 times the initial record and in $30-35^{\circ} \mathrm{C}$, OD was only 2.8 times (Figure 1). The CC and DW also support our results (Figure 2 and 3 ). Higher number of cells and dry weight were observed at $25-30^{\circ} \mathrm{C}$, which showed an increase of about 2.9 and 3.2 times, respectively, from the initial cultures. On the other hand, at $30-35^{\circ} \mathrm{C}$ the number of cells and dry weight increased only 2.7 times.

The two sets of temperature i.e. $25-30^{\circ} \mathrm{C}$ and $30-35^{\circ} \mathrm{C}$ under

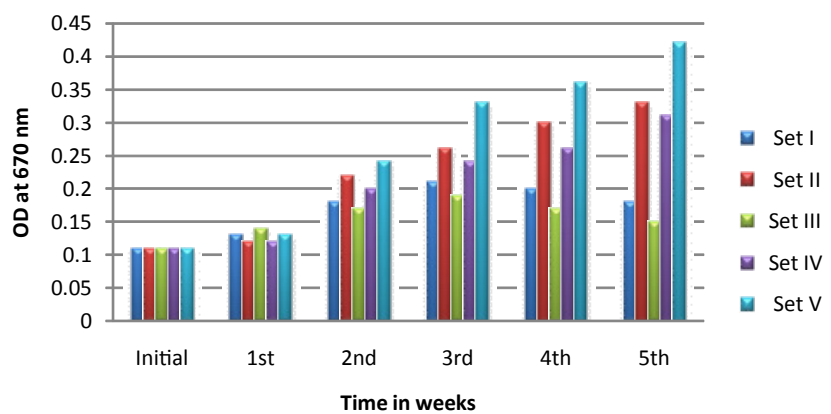

Figure 1: Effects of different culture conditions on growth (OD at $670 \mathrm{~nm}$ ) of Chlorella vulgaris.

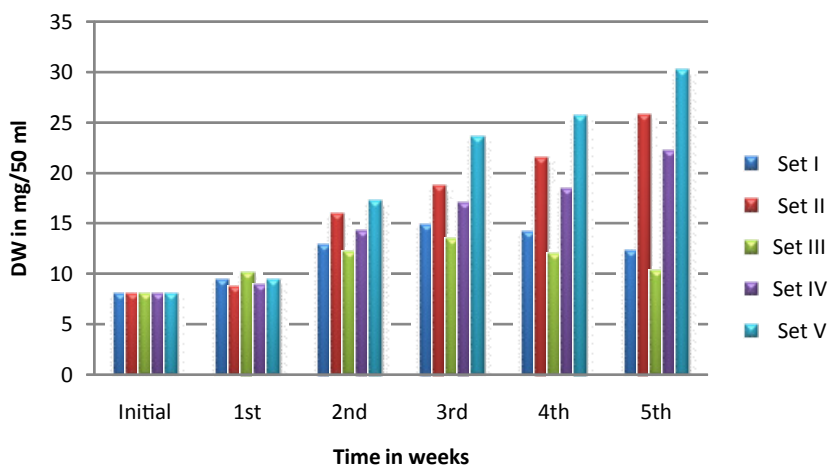

Figure 2: Effects of different culture conditions on growth (DW, in $\mathrm{mg} / 50 \mathrm{ml}$ ) of Chlorella vulgaris. 


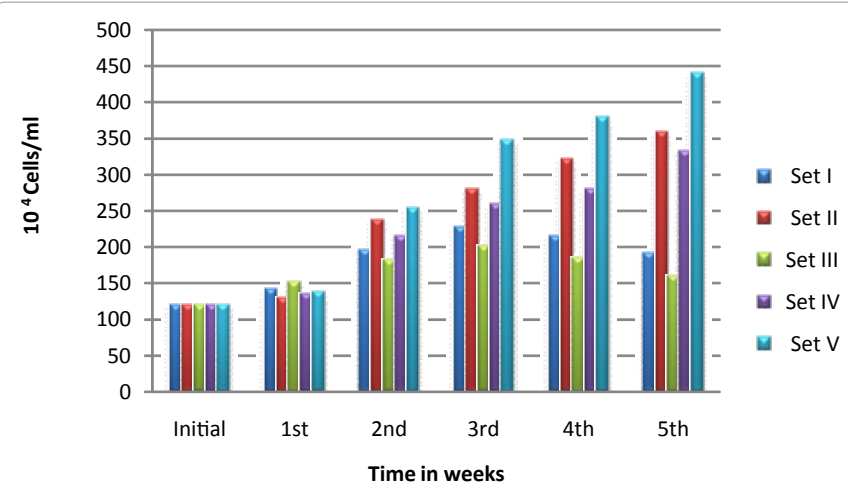

Figure 3: Effects of different culture conditions on growth (CC) of Chlorella vulgaris.

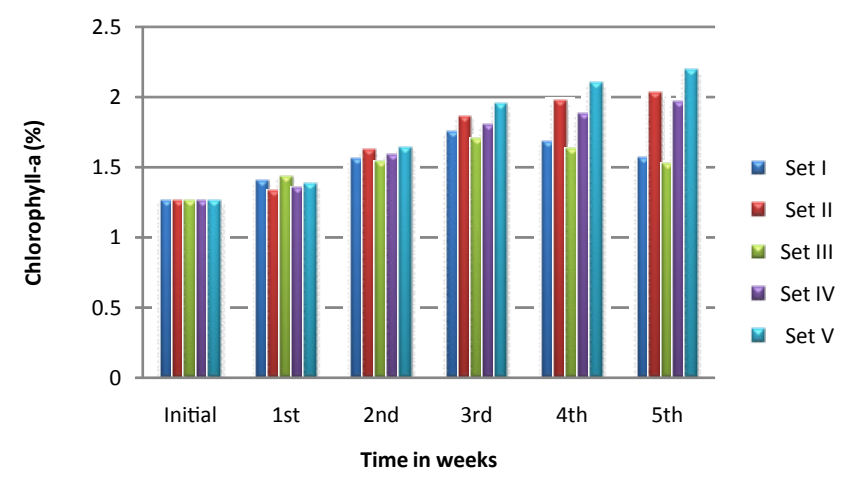

Figure 4: Effects of different culture conditions on chlorophyll-a (\%) of Chlorella vulgaris.

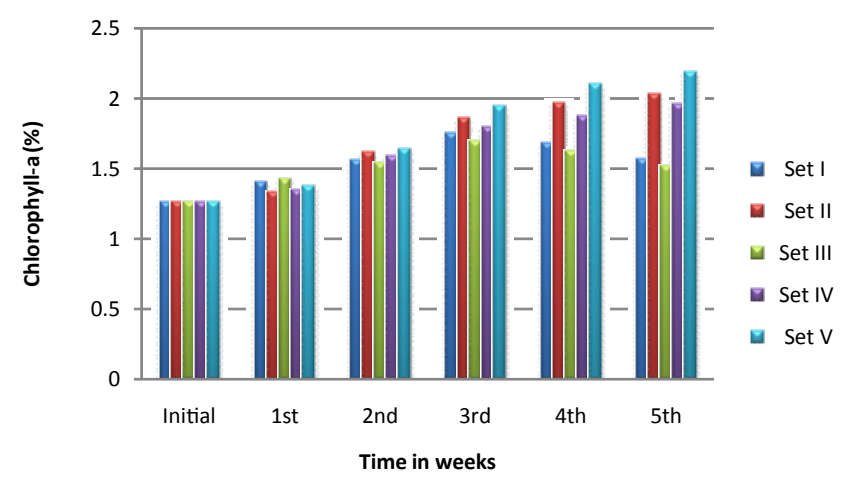

Figure 5: Effects of different culture conditions on chlorophyll-b (\%) of Chlorella vulgaris.

continuous illumination, the higher growth rate showed in $25-30^{\circ} \mathrm{C}$, where OD and DW observations indicated an increase of 1.6 and 1.5 times, respectively, from the initial record at the end of $5^{\text {th }}$ week. The CC also supports these data. The number of cells increased at $25-30^{\circ} \mathrm{C}$ showed about 1.6 times from the initial count, whereas at $30-35^{\circ} \mathrm{C}$ the OD and DW raised 1.3 and 1.2 times correspondingly, and the CC increased 1.3 times from the initial record.

The maximum biomass concentration as OD, DW and CC were observed under natural day light condition in north facing window at $25-30^{\circ} \mathrm{C}$, where OD increased 3.8 times the initial record and DW showed an increase of about 3.7 times from the initial observation. Cell count also correlates the above result and increased about 3.6 times the initial number (Figure 3).

\section{Biochemical production}

The pigment content of the algae also correlates with the growth of Chlorella vulgaris in normal culture condition. The higher amount of $\mathrm{Chl}-\mathrm{a}$ and Chl-b were found in cultures receiving natural day light in north facing window at $25-30^{\circ} \mathrm{C}$ i.e. $2.16 \%$ and $0.59 \%$ correspondingly, after a period of five weeks, followed by $2.03 \%$ and $0.52 \%$ in alternate light and dark period at $25-30^{\circ} \mathrm{C}, 1.96 \%$ and $0.50 \%$ in alternate light and dark period at $30-35^{\circ} \mathrm{C}, 1.57 \%$ and $0.42 \%$ in continuous light at $25-30^{\circ} \mathrm{C}$ and least amount of Chl-a and Chl-b content were observed in continuous light at $30-35^{\circ} \mathrm{C}$ i.e. $1.52 \%$ and $0.39 \%$, respectively (Figures 4 and 5).

All the cultures receiving different culture conditions show dissimilar change in total carotenoids accumulation. In all culture conditions, carotenoid content enhanced up to the $5^{\text {th }}$ week, but in continuous light with both temperature sets, carotenoid content significantly increased after $3^{\text {rd }}$ week onwards, therefore, higher amount of carotenoid content was shown in continuous light at $30-35^{\circ} \mathrm{C}$ i.e. $0.440 \%$, followed by in continuous light at $25-30^{\circ} \mathrm{C}$, natural day light at $25-30^{\circ} \mathrm{C}$, alternate light and dark period at $30-35^{\circ} \mathrm{C}$ and alternate light and dark period at $25-30^{\circ} \mathrm{C}$ i.e. $0.427 \%, 0.385 \%, 0.378 \%$ and $0.367 \%$, respectively (Figure 6).

The total protein contents were directly proportionate to the growth and chlorophyll contents. Continuous light and higher temperature negatively affected protein concentration. The highest amount of protein was found in natural day light at $25-30^{\circ} \mathrm{C}$ i.e. $52.6 \%$ followed by

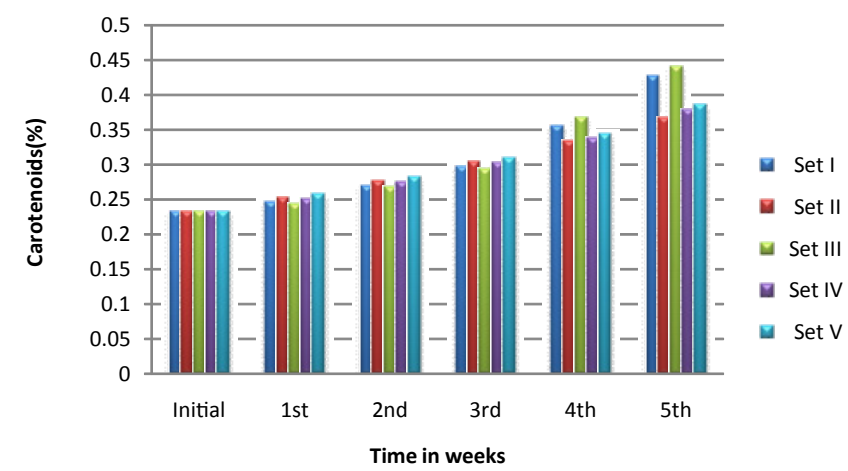

Figure 6: Effects of different culture conditions on total carotenoids (\%) of Chlorella vulgaris

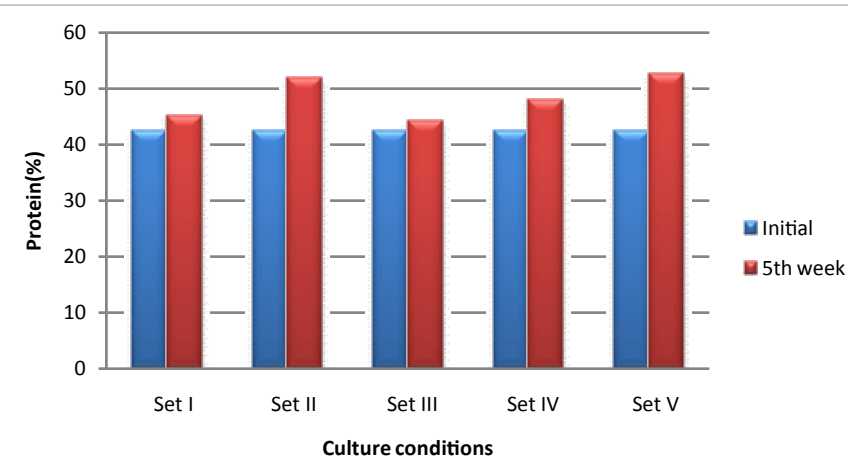

Figure 7: Effects of different culture conditions on total protein (\%) content of Chlorella vulgaris. 


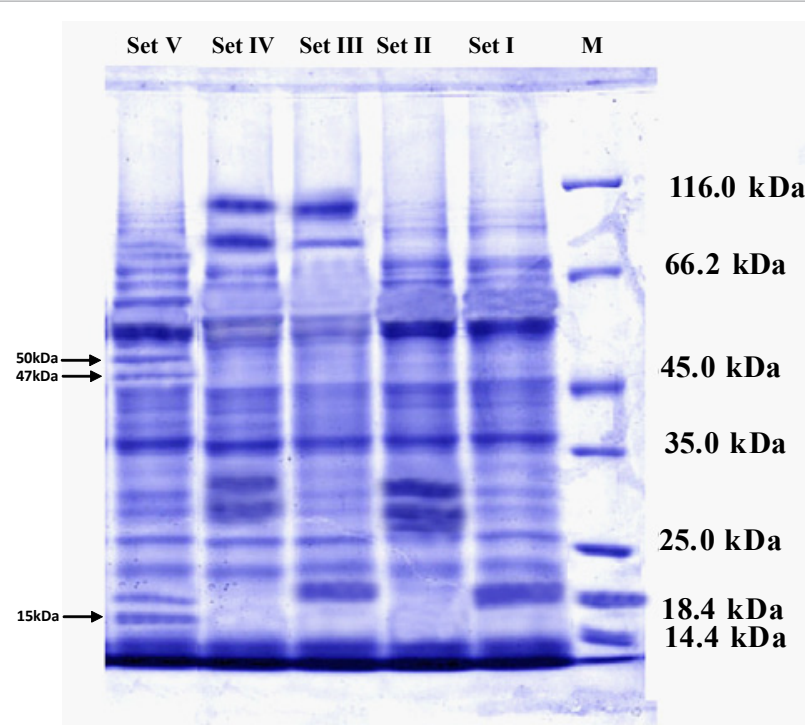

Figure 8: SDS-PAGE of Chlorella vulgaris, where $\mathrm{M}$ is a marker.

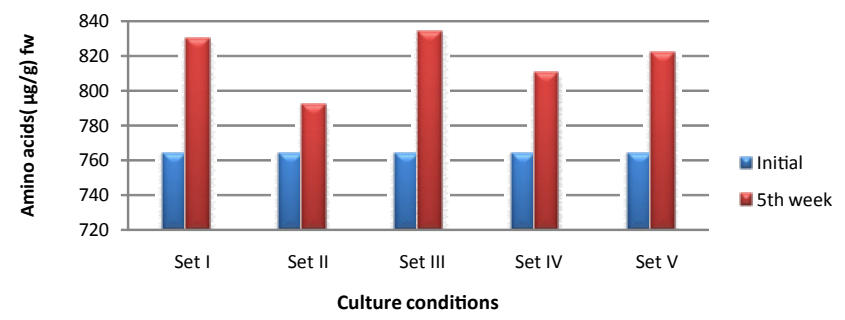

Figure 9: Effects of different culture conditions on total free amino acids $(\mu \mathrm{g} / \mathrm{g}$ $\mathrm{fw}$ ) of Chlorella vulgaris.

$51.9 \%$ in alternate light and dark period at $25-30^{\circ} \mathrm{C}, 47.9 \%$ in alternate light and dark period at $30-35^{\circ} \mathrm{C}, 45.2 \%$ in continuous light at $25-30^{\circ} \mathrm{C}$, and lowest protein content was observed in continuous light at $30-35^{\circ} \mathrm{C}$ i.e. $44.2 \%$ (Figure 7 ).

Qualitative estimation of protein by SDS PAGE showed different polypeptide profile, at different culture conditions. Some bands were common in all culture conditions, like $23 \mathrm{KDa}, 26 \mathrm{KDa}$ and $36 \mathrm{KDa}$. Furthermore, some were specific for light condition and temperature conditions. $28 \mathrm{KDa}$ to $32 \mathrm{KDa}$ band with higher density were found common in both sets of alternate light, and with modest lesser density found in natural day light condition. $19 \mathrm{KDa}$ to $21 \mathrm{KDa}$ band with elevated concentration were found common in both sets of continuous light, and $19 \mathrm{KDa}$ was also present in natural day light condition. In both $25-30^{\circ} \mathrm{C}$ temperature sets, $55 \mathrm{KDa}, 75 \mathrm{KDa}, 76 \mathrm{KDa}$ band were present, and approximate $75 \mathrm{KDa}$ and $83 \mathrm{KDa}$ feadible bands were also present in natural day light condition. $83 \mathrm{KDa}, 99 \mathrm{KDa}$ to 101 $\mathrm{KDa}$ band were present with higher density, in both sets of $30-35^{\circ} \mathrm{C}$ temperature condition. Some unique bands like $15 \mathrm{KDa}, 47 \mathrm{KDa}$ and $50 \mathrm{KDa}$ were present in natural day light at $25-30^{\circ} \mathrm{C}$ (Figure 8).

The total free amino acids showed inverse trend from proteins, higher amount of free amino acids were found in continuous light at $30-35^{\circ} \mathrm{C}$ i.e. $834 \mu \mathrm{g} / \mathrm{g} \mathrm{fw}$, followed by $830 \mu \mathrm{g} / \mathrm{g} \mathrm{fw}$ in continuous light at $25-30^{\circ} \mathrm{C}, 822 \mu \mathrm{g} / \mathrm{g} \mathrm{fw}$ in natural day light at $25-30^{\circ} \mathrm{C}, 810 \mu \mathrm{g} / \mathrm{g} \mathrm{fw}$ in alternate light and dark period at $30-35^{\circ} \mathrm{C}$ and $792 \mu \mathrm{g} / \mathrm{g} \mathrm{fw}$ in alternate light and dark period at $25-30^{\circ} \mathrm{C}$ (Figure 9) (Table 1).

\section{Discussion}

Highest biomass concentration (OD, CC and DW) were observed at natural day light and $25-30^{\circ} \mathrm{C}$ temperature. These observations were also supported by higher contents of Chl-a, Chl-b and total proteins, however, total carotenoids and free amino acids showed different trend. Changes in irradiances and photoperiods, the growth of Chlorella vulgaris respond differently [19]. Natural day light and $25-30^{\circ} \mathrm{C}$ temperature were favorable for overall growth of $\mathrm{C}$. vulgaris. Maximum specific growth rate of C. pyrenoidosa, increased uniformly with enhanced temperature, in the range $22^{\circ} \mathrm{C}$ to $30^{\circ} \mathrm{C}$ [20], and more increase of temperature resulted in a drop of specific growth rate and cells are unable to grow at temperature above $33^{\circ} \mathrm{C}$ [21], so the optimum temperature for C. vulgaris is $25-30^{\circ} \mathrm{C}$.

It was observed in our study that in the $1^{\text {st }}$ week of experiment, the growth of Chlorella under continuous illumination, was greater than the alternate light and natural day light. This is for the reason that the incidence of adequate light energy under continuous light in the $1^{\text {st }}$ week of cultivation, during cell metabolism process, therefore, $C$. vulgaris is able to grow speedily. Similar observations were reported by scientists [22].

After $3^{\text {rd }}$ week onwards, in both sets of continuous light, the growth and chlorophyll content were reduced and carotenoid content was increased rapidly. This is because of photooxidation reaction in the cells, owed to excess light that cannot be absorbed by the photosynthetic apparatus. The changes in pigments are related to an adaptation mechanism, chlorophyll was reduced due to photooxidation, and carotenoids were increased to protect photooxidative damage of the cell [19], in addition to that, in higher light the algae synthesized smaller photosynthetic units, most probably to prevent photo damage, however, in low light larger photosynthetic units are found probably to aid light harvesting [22].

In general, rapidly growing microalgal cells were exhibited by a higher protein and low carbohydrate content [4], so the rapidly growing cells of natural day light at $25-30^{\circ} \mathrm{C}$ showed higher amount of protein. Similar observations found in Ankistrodesmus fusiformis [23]. Higher temperature showed decrease in protein content and a concurrent accumulation of carbohydrates in Spriluna sp [24], and lower degree of illumination favors higher protein in Chlorella [25]. In light-dark cycle, light favors the accumulation of carbohydrate and in the absence of light, cells obtain their energy by metabolizing carbohydrate, and this energy is used to synthesis protein.

Not too much variation found in the total free amino acid concentration at different culture conditions, though, amino acids showed inverse trend from the protein. Similar observations were noted that suppressed protein biosynthesis encouraged free amino acid accumulation in C. vulgaris [26], due to degradation of protein

\begin{tabular}{|l|l|l|l|l|l|}
\hline $\begin{array}{l}\text { Culture } \\
\text { Condi- } \\
\text { tions }\end{array}$ & $\begin{array}{l}\text { Chlorophyll-a } \\
(\%)\end{array}$ & $\begin{array}{l}\text { Chlorophyll -b } \\
(\%)\end{array}$ & $\begin{array}{l}\text { Carotenoids } \\
(\%)\end{array}$ & $\begin{array}{l}\text { Protein } \\
(\%)\end{array}$ & $\begin{array}{l}\text { Amino } \\
\text { Acids } \\
(\boldsymbol{\mu} \mathbf{g} / \mathbf{g ~ f w})\end{array}$ \\
\hline Set I & $1.57 \pm 0.025^{\mathrm{a}}$ & $0.42 \pm 0.025^{\mathrm{a}}$ & $0.427 \pm 0.004^{\mathrm{a}}$ & $45.2 \pm 1.84^{\mathrm{a}}$ & $830 \pm 2.5^{\mathrm{a}}$ \\
\hline Set II & $2.03 \pm 0.035^{\mathrm{b}}$ & $0.52 \pm 0.045^{\mathrm{b}}$ & $0.367 \pm 0.004^{\mathrm{b}}$ & $51.9 \pm 1.40^{\mathrm{b}}$ & $792 \pm 5.68^{\mathrm{b}}$ \\
\hline Set III & $1.52 \pm 0.030^{\mathrm{c}}$ & $0.39 \pm 0.045^{\mathrm{a}}$ & $0.440 \pm 0.002^{\mathrm{c}}$ & $44.2 \pm 1.27^{\mathrm{a}}$ & $834 \pm 3.60^{\mathrm{a}}$ \\
\hline Set IV & $1.96 \pm 0.025^{\mathrm{d}}$ & $0.50 \pm 0.040^{\mathrm{b}}$ & $0.378 \pm 0.004^{\mathrm{d}}$ & $47.9 \pm 1.62^{\mathrm{c}}$ & $810 \pm 2.51^{\mathrm{c}}$ \\
\hline Set V & $2.16 \pm 0.025^{\mathrm{e}}$ & $0.59 \pm 0.045^{\mathrm{c}}$ & $0.385 \pm 0.002^{\mathrm{e}}$ & $52.6 \pm 1.10^{\mathrm{b}}$ & $822 \pm 3.00^{\mathrm{d}}$ \\
\hline
\end{tabular}

Table1: Effect of different culture conditions on biochemical contents of Chlorella vulgaris in $5^{\text {th }}$ week. Values are means \pm Standard deviation $(n=3)$. For each individual experiment, variable means with the same letter are not significantly different $(p<0.05)$ 
Citation: Sharma R, Singh GP, Sharma VK (2012) Effects of Culture Conditions on Growth and Biochemical Profile of Chlorella Vulgaris. J Plant Pathol Microb 3:131. doi:10.4172/2157-7471.1000131

molecules [27] or different environmental stresses [28].

Enhancement of protein expression occurred in a large number of protein species, under stress conditions. $28 \mathrm{KDa}$ to $32 \mathrm{KDa}$ band were found similar to Dunaliella salina and these bands were highly reduced in both sets of continuous light. It may be related to the proteins of the LHC-II (Light harvesting complex of photosystem II), and in high irradiance stress is the down-sizing of the chl-a and chl-b LHCII antenna by unknown mechanism [29]. This is one adaptive mechanism of green algae to stress. Protein bands of $19 \mathrm{KDa}$ to 21 KDa were similar to ELIPs (Early light inducible proteins) of land plants, and Dunaliella Cbr (Carotenoid binding protein), which serves to protect the photosystem against too much radiation and possibly anti-photooxidative role of this protein [30]. The $55 \mathrm{KDa}$ band may be related to RuBP carboxylase, which was also found in C. protothecoides [31] and $75 \mathrm{KDa}, 76 \mathrm{KDa}$ bands may be related to normal optimum temperature $\left(25^{\circ} \mathrm{C}-30^{\circ} \mathrm{C}\right)$. In higher temperature i.e. $30-35^{\circ} \mathrm{C}, 83 \mathrm{KDa}$, and $99 \mathrm{KDa}$ to $101 \mathrm{KDa}$ bands were seen, which may be related to heat shock proteins (HSPs). HSPs prevent the cell from thermo-damage and help to survive in higher temperature. In our experiment, the natural day light at $25-30^{\circ} \mathrm{C}$ temperature was proved proficient, as distinct banding pattern with unique polypeptides such as $15 \mathrm{KDa}, 47 \mathrm{KDa}$ and $50 \mathrm{KDa}$. On the other hand, $23 \mathrm{KDa}, 26 \mathrm{KDa}$ and $36 \mathrm{KDa}$ appeared in all samples, these bands were not affected by light and temperature.

Light/dark cycle was more supportive for growth than other regimes, because cell number is sustained longer in exponential phase longer [19], and photoperiodicity also save the consumption of light energy and increase light energy efficiency [22].

\section{Conclusion}

Due to high nutritional value, natural pigments and anti-oxidant activity, Chlorella vulgaris is used in food and pharmaceuticals industries. Therefore, objective of this research was to optimize the best culture condition for its high biomass, chlorophyll contents, total protein, total carotenoids and total free amino acids. It has been mentioned above that natural day light at $25-30^{\circ} \mathrm{C}$ showed highest concentration of biomass, chlorophyll and protein contents, but carotenoids and amino acids were found little lower from the maximum in natural day light at $25-30^{\circ} \mathrm{C}$. A slight stress condition is developed in natural day light due to sun light intensity or photoperiod, which favors the accumulation of carotenoids and free amino acids, without affecting the concentration of biomass, chlorophyll and protein contents. Therefore, we recommend culturing Chlorella for its high nutritive purpose at natural day light at $25-30^{\circ} \mathrm{C}$.

\section{Acknowledgements}

The authors wish to thank the Principal, MSJ Govt. P G College, Bharatpur (Rajasthan) and the Head, Department of Botany, University of Rajasthan for lab and library facilities.

\section{References}

1. Falkowski PG, Dubinsky Z, Wyman K (1985) Growth irradiance relationships in phytoplankton. Limnol Oceanogr 30: 311-321.

2. Raven JA, Geider RJ (1988) Temperature and algal growth. New Phytol 110: 441-461.

3. Brown MR, Hohmann S (2002) Effects of irradiance and growth phase on the ascorbic acid content of Isochrysis sp. T.ISO (Prymnesiophyta). J Appl Phycol 14: $211-214$

4. Sayegh FAQ, Montagnes DJS (2011) Temperature shifts induce intraspecific variation in microalgal production and biochemical composition. Bioresour Technol 102: 3007-3013.
5. Khoeyi ZA, Seyfabadi J, Ramezanpour Z (2012) Effect of light intensity and photoperiod on biomass and fatty acid composition of the microalgae, Chlorella vulgaris. Aquaculture International 20: 41-49.

6. Jacquet S, Partensky F, Marie D, Casotti R, Vaulot D (2001) Cell cycle regulation by light in Prochlorococcus strains. Appl Environ Microbiol 67: 782-790.

7. Necas J (1982) Comparision of dependence of growth and sexual reproduction of Chlamydomonas geitleri on temperature and irradiance. Biol Plant 24: 311 313

8. Woodford E, Haschenard, Paul W, Behrans (1990) Growth \& polysaccharide content of the green alga chlamydomonas ulvaensis. J Phycol 26.

9. Patel RJ (1970) Growth of members of Cladophorales in experimental cultures Phykos 10: 40-53.

10. Chalifour A, Juneau P (2011) Temperature-dependent sensitivity of growth and photosynthesis of Scenedesmus obliquus, Navicula pelliculosa and two strains of Microcystis aeruginosa to the herbicide atrazine. Aquat Toxicol 103: 9-17.

11. Nizam J (1960) Desmid and Chlorella in experimental cultures. Brit Phycol Bull 2: 18.

12. Mogili T, Vidyavati (1985) Mutagenic effect of some analgesic and antipyretic drugs on Cladophora crispate (Roth.) Kuetz Phykos 24: 88-94.

13. Sharma R, Singh GP, Sharma VK (2011) Comparison of different media formulations on growth, morphology and chlorophyll content of green alga Chlorella vulgaris. Int J Pharm Bio Sci 2: 509-516.

14. Parson TR, Strickland JDH (1965) Discussion of spectrophotometric determination of marine plant fragments with revised equation for aseartaning Chlorophyll and Carotenoids. J Marine Res 21: 155-163.

15. Jenson A (1978) Chlorophylls and carotenoids. Handbook of phycological methods. Physiological and biochemistry methods. Cambridge University press, Cambridge.

16. Lowry OH, Rosebrough NJ, Farr AL, Randall RJ (1951) Protein measurement with the Folin phenol reagent. J Biol Chem 193: 265-275

17. Laemmli UK (1970) Cleavage of structural proteins during the assembly of the head of bacteriophage T4. Nature 227: 680-685.

18. Lee YP, Takahashi T (1966) An improved colorimetric determination of amino acids with the use of ninhydrin. Anal Biochem 14: 71-77.

19. Seyfabadi J, Ramezanpour Z, Amini KZ (2011) Protein, fatty acid, and pigment content of Chlorella vulgaris under different light regimes. J Appl Phycol 23 721-726.

20. Hosono H, Uemura I, Takumi T, Nagamune T, Shimomura N, et al. (1997) Effects of culture temperature shift and light-dark time cycle on the cellular sugar accumulation of Chlorella pyrenoidosa. Bioprocess Biosyst Eng 16: 193197.

21. Ong SC, Kao CY, Chiu SY, Tsai MT, Lin CS (2010) Characterization of the thermal-tolerant mutants of Chlorella $s p$. with high growth rate and application in outdoor photobioreactor cultivation. Bioresour Technol 101: 2880-2883.

22. Wijanarko A, Dianursanti, Witarto AB, Soemantojo RW (2004) Effect of photoperiodicity on $\mathrm{CO}_{2}$ fixation by Chlorella Vulgaris Buitenzorg in bubble column photobioreactor for food supplement production. Makara Seri Teknologi 8: $35-43$.

23. Singh GP, Srivastava P (1991) Impact of varied culture conditions on growth and morphology of Ankistrodesmus fusiformis. Journal of the Indian Botanical Society 70: 341-345.

24. De Oliveira MACL, Monteiro MPC, Robbs PG, Leite SGF (1999) Growth and chemical composition of Spirulina maxima and Spirulina platensis biomass at different temperatures. Aquaculture International 7: 261-275.

25. Herman (1956) Production of protein, lipids and carbohydrates by culture of algae. US Patent Office.

26. Afkar E, Ababna H, Fathi AA (2010) Toxicological response of the green alga chlorella vulgaris, to some heavy metals. Am J Environ Sci 6: 230-237.

27. El-Sheekh MM, Fathy AA (2009) Variation of some nutritional constituents and fatty acid profiles of Chlorella vulgaris Beijerinck grown under auto and heterotrophic conditions. International J Bot 5: 153-159. 
Citation: Sharma R, Singh GP, Sharma VK (2012) Effects of Culture Conditions on Growth and Biochemical Profile of Chlorella Vulgaris. J Plant Pathol Microb 3:131. doi:10.4172/2157-7471.1000131

Page 6 of 6

28. Khairy HM, Ali EM, Dowidar SM (2011) Comparative effects of autotrophic and heterotrophic growth on some vitamins, 2,2-diphenyl-1-picrylhydrazyl (DPPH) free radical scavenging activity, amino acids and protein profile of Chlorella vulgaris Beijerinck. African J Bioteh 10: 13514-13519.

29. Webb MR, Melis A (1995) Chloroplast response in Dunaliella salina to irradiance stress (Effect on Thylakoid Membrane Protein Assembly and Function). Plant Physiol 107: 885-893.
30. Krol M, Maxwell DP, Huner NPA (1997) Exposure of Dunaliella salina to low temperature mimics the high light- induced accumulation of carotenoids and the carotenoid binding protein (Cbr). Plant Cell Physiol 38: 213-216.

31. Valliammai T, Gnanam A, Dharmalingam K (1987) Heat shock response in Chlorella protothecoides Plant Cell Physiol 28: 975-985. 